\title{
Manejo de perforaciones iatrogénicas desfavorables durante colocación de poste usando agregado de trióxido mineral: reporte de dos casos
}

Management of unfavorable iatrogenic perforations during post placement using mineral trioxide aggregate: report of two cases

\author{
Manuel Palomino-Delgado ${ }^{1}$, Hernán Coaguila-Llerena ${ }^{2}$, Carlos Mendiola-Aquino ${ }^{3}$, Gisele Faria ${ }^{2}$ \\ RESUMEN
}

Dos pacientes acudieron al departamento de Endodoncia para evaluar las piezas dentarias 35 y 46 . Ambas piezas tenían antecedente de colocación de poste en un tratamiento endodóntico reciente en la pieza 46, y hacía 3 meses en la pieza 35, con perforaciones de gran tamaño, evidentes en el tercio medio radicular. En ambos casos se recomendó el sellado de perforaciones. Se retiraron los postes y se colocó MTA Angelus blanco (Angelus, Londrina, PR, Brasil) en las perforaciones de ambos casos. Finalmente, los conductos radiculares se obturaron utilizando la técnica de onda continua. Los controles de 6 meses, 2 años y 6 años (pieza 35) y los controles de 3 meses, 1 año y 3 años (pieza 46) mostraron una evolución favorable. Se puede concluir que la aplicación de MTA en perforaciones iatrogénicas promueve buenos resultados, permitiendo el mantenimiento de los dientes en función dentro de la cavidad oral.

PALABRAS CLAVE: endodoncia, agregado de trióxido mineral, tratamiento del conducto radicular.

\section{ABSTRACT}

Two patients attended at the Endodontics Department to evaluate teeth 35 and 46. Both teeth had a history of post placement in a recent endodontic treatment in tooth 46, and 3 months ago in tooth 35 , with evident large perforations in the middle third of their roots. In both cases, perforation sealing was recommended. The posts were removed and white MTA Angelus (Angelus, Londrina, PR, Brazil) was placed in the perforations of both cases. Finally, the root canals were obturated using the continuous wave technique. The 6-month, 2-year

Department of Endodontics, Universidad Científica del Sur. Lima, Peru.

Department of Restorative Dentistry, Araraquara School of Dentistry, São Paulo State University - UNESP, Araraquara, 14801-903. São Paulo, Brazil.

3 Department of Endodontics, Universidad Peruana Cayetano Heredia. Lima, Peru. 
and 6-years follow-ups (tooth 35), and 3-month, 1-year and 3-year follow-ups (tooth 46) showed a favorable evolution. It can be concluded that the application of MTA in iatrogenic perforations promoted good results, allowing the maintenance of the teeth in function.

KEYWORDS: endodontics, mineral trioxide aggregate, root canal therapy.

\section{INTRODUCTION}

Root canal perforations are artificial communications between the root canal and the supporting tissues of the tooth or the oral cavity (1). They can be classified as pathological if they are caused by caries or root resorption, or as iatrogenic if they are produced during root canal treatment (2). The presence of pulp stones, calcification, rotated tooth, extensive caries, misidentification of the root canal, or posts are factors that can hinder access to the root canal and trigger perforations (3). Regarding posts, their magnitude is related to greater dentin excavation (2), which may lead to catastrophic consequences. Theoretically, a perforation into supporting tissues alone might not necessarily cause irreversible inflammation or failure; however, if there is bacterial inflammation the healing process will not occur $(2,3)$. Thus, painful conditions, suppurations, abscesses or even fistulas can occur (1). Traditionally, various materials have been used to seal perforations, such as calcium hydroxide, amalgam, reinforced zinc oxide cement; however, calcium silicate-based cements, e.g., the mineral trioxide aggregate (MTA) promote a better tissue response (3-5).

The MTA is a bioactive endodontic material that was initially developed in the 90 s as a material for sealing lateral perforations (6), and is mainly composed of calcium and silicate elements (7), which set in the presence of humidity (8). MTA has adequate physicochemical properties (9), promotes low cytotoxicity (10), and provides adequate sealing (11). It is important to note that MTA is marketed in 2 forms: gray and white. The white MTA was introduced due to the potential discoloration effects of gray MTA, caused mainly by its radiopacifier, bismuth oxide (12). MTA has been described as an appropriate material for root-end filling, vital pulp therapy, apical barrier formation for teeth with necrotic pulps and open apexes and perforation repair (13).
The present case reports the management of two unfavorable iatrogenic perforations during post placement with mineral trioxide aggregate.

\section{Case 1}

An asymptomatic 25-year-old female patient was referred to the endodontics department to evaluate the right mandibular first molar (FDI tooth No. 46). The medical history of the patient was noncontributory. The dental history included a recent root canal treatment and post placement in the affected tooth. The clinical examination showed that there were no sensitivity to percussion or palpation and no extraoral or intraoral swelling. The radiographic examination revealed a radiopaque element in the distal root, which was compatible with metal post, perforating the middle third of the root. The diagnosis was "previously treated" and "normal periapical tissues". The treatment alternatives were discussed together with the patient, who consented to perform the removal of the metal post followed by sealing of perforation and replacement of restoration.

The local anesthesia was administered by oral infiltration of $2 \%$ lidocaine with 1: 100,000 adrenaline (Alphacaine, Rio de Janeiro, RJ, Brazil). Then, rubber dam isolation was performed, the previous restoration was removed, the access was obtained, and the metal post was removed using an ultrasonic tip (E12, Helse Ultrasonic, Santa Rosa de Viterbo, SP, Brazil) coupled to an ultrasonic device (MiniEndo, Kerr Endodontics, Brea, CA, USA). A non-bleeding large perforation, with approximately $2-3 \mathrm{~mm}$ in diameter, was identified in the middle third of the distal root. Before sealing, irrigation with $2 \%$ chlorhexidine (Maquira, Maringá, PR, Brazil) was performed using a $27 \mathrm{G}$ side-vented needle (Endo-Eze Irrigator Tip, Ultradent Products, South Jordan, UT, USA). After drying the perforation site with paper points, a matrix of calcium sulfate mixed with distilled water was placed, which acted as a barrier between bone and tooth. Once set the matrix after approximately 1 minute, the white MTAAngelus 
(Angelus, Londrina, PR, Brazil) repair cement was placed using an MTA Applicator (Angelus). After 24 $\mathrm{h}$, the cervical and middle thirds of the distal canal were obturated using gutta-percha and AH Plus sealer (Dentsply DeTrey, Konstanz, Germany) using the continuous wave technique. The access cavity was sealed with a glass ionomer cement (Fuji IX GP Fast; GC Corporation, Tokyo, Japan). An indirect resin restoration was placed after adjustment of occlusion and proximal contacts. The 1-month, 1-year and 3-year follow-up showed favorable evolution (Figure $1)$.

\section{Case 2}

A symptomatic 43-year-old female patient without non-contributory medical history was evaluated at the endodontics department of the Central Hospital of the Peruvian Air Force.
The dental history included a root canal treatment and post placement in the second mandibular premolar (FDI 35 tooth) 3 months ago, a temporary restoration and spontaneous pain in the left mandibular area. The clinical examination showed that there was sensitivity to percussion; however, there was not extraoral or intraoral swelling. The inadequate adaptation of the provisional restoration allowed the leakage of oral fluids into the tooth. The radiographic examination revealed radiopaque line compatible with fiber post, which perforated the middle third of the root, as well as bone loss adjacent to the perforation site.

The diagnosis was previously treated and symptomatic apical periodontitis, so the nonsurgical endodontic treatment, including the removal of the fiber post and sealing the perforation was recommended. The patient consented to perform the procedures.
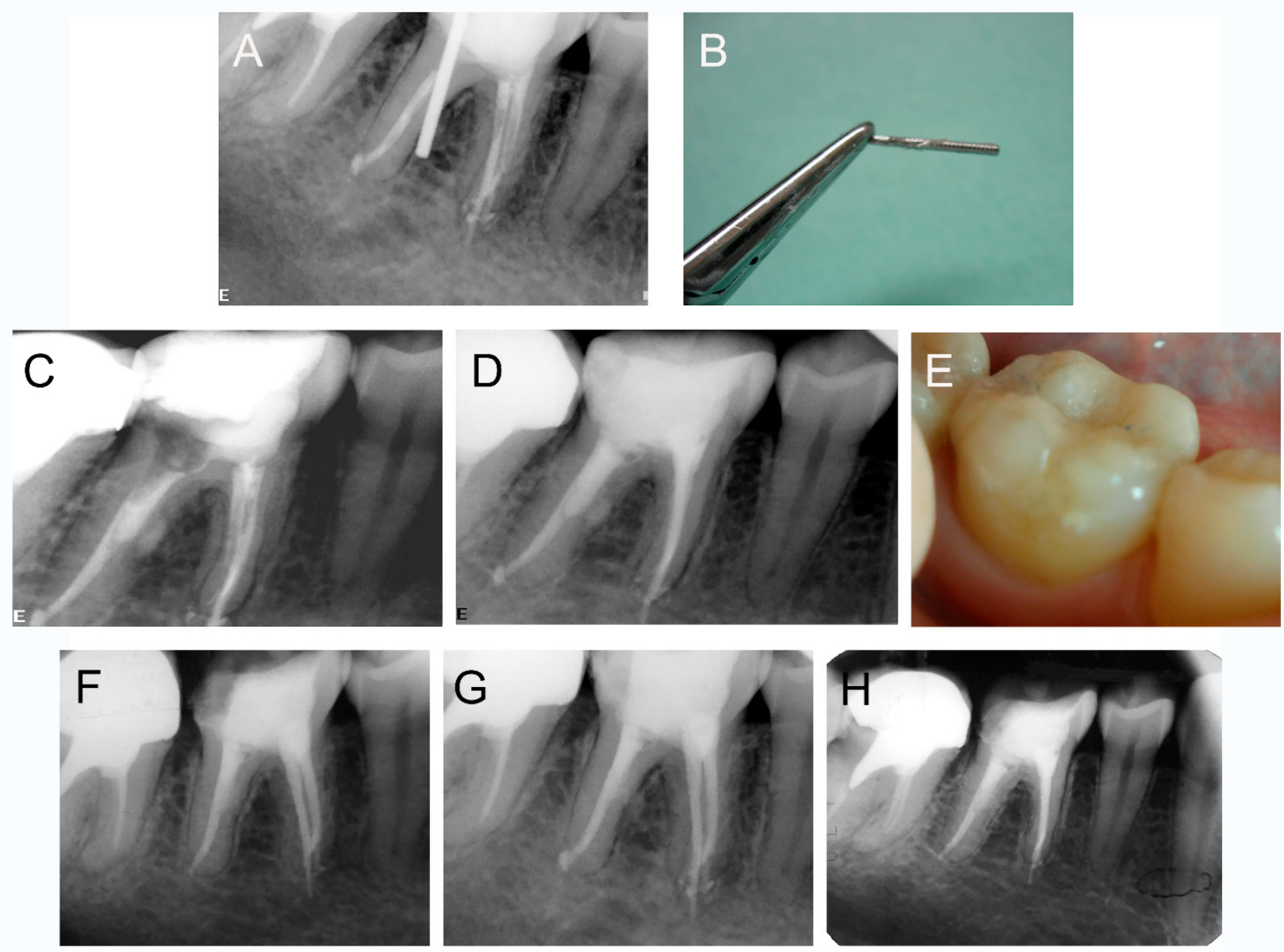

Figure 1. Illustrative images of the management of case 1, tooth 46. (A) Preoperative periapical radiograph. (B) Metal post removed from root canal. (C) Periapical radiograph after application of mineral trioxide aggregate into perforation site. (D) Postoperative periapical radiograph after final restoration. (E) Clinical view of the final restoration. (F) 3-month follow-up. (G) 1-year follow-up. (H) 3-year follow-up. 
The local anesthesia was administered by oral infiltration of $2 \%$ lidocaine with 1: 100,000 adrenaline (Alphacaine). After absolute isolation of the tooth, the fiber post was removed using an ultrasonic tip (E12, Helse Ultrasonic) coupled to an ultrasonic device (MiniEndo, Kerr Endodontics), which allowed an easy removal with a tweezer. A non-bleeding large perforation, with approximately $2-3 \mathrm{~mm}$ in diameter, was identified and provisionally sealed with polytetrafluoroethylene (Teflon) tape to allow retreatment. The filling material was removed using the Mtwo retreatment system (VDW, Munich, Germany) using an R25.05 file complemented with Mtwo system (VDW) up to 40.04 file. The irrigation protocol was performed using $2.5 \%$ sodium hypochlorite $(\mathrm{NaOCl})$ using a $27 \mathrm{G}$ side-vented needle (Endo-Eze Irrigator Tip, Ultradent Products). Once removed the Teflon, a calcium hydroxide dressing was placed in the canal and perforation for 15 days. In the second session, it was observed that the coronary remnant of the tooth had fractured; however, without compromising the sealing of the provisional restoration or the sufficient coronary remnant for the restoration, which allowed to continue the treatment. The calcium hydroxide was removed from the canal, leaving the residual paste in the perforation to act as a matrix for the placement of white MTA Angelus (Angelus) repair material, which was placed using an MTA Applicator (Angelus). The canal was obturated using gutta-percha points and $\mathrm{AH}$ Plus sealer (Dentsply DeTrey) using the continuous wave technique. A fiber post was placed immediately, and subsequently, a crown. The 6-month follow-up showed a favorable evolution. The 2-year follow-up showed that another colleague placed a metal post and a metal-ceramic crown.

Although with different prosthetic treatment, the 6-year follow-up showed a favorable evolution and bone neo-formation at the perforation site. (Figure 2).
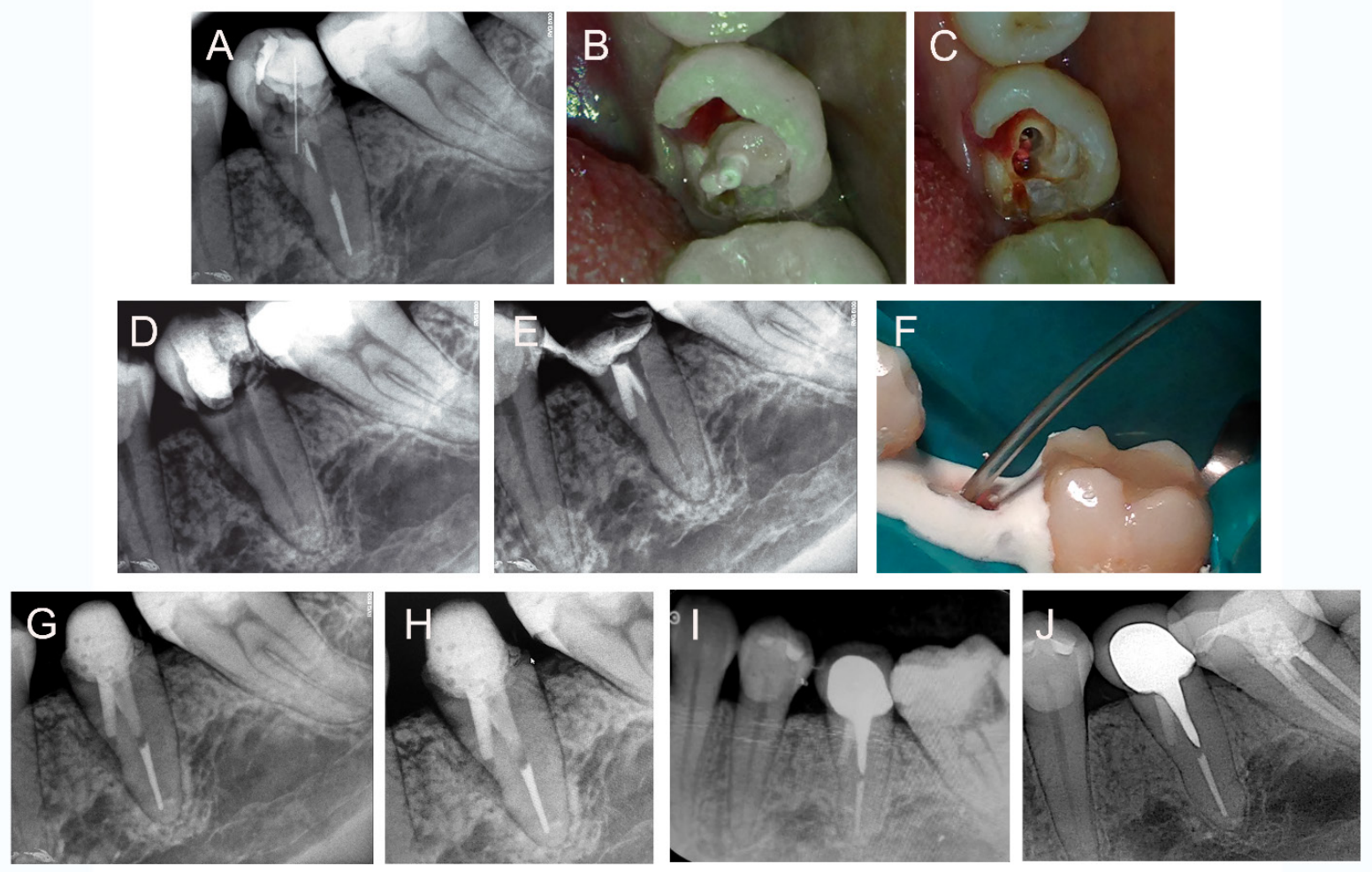

Figure 2. Illustrative images of the management of case 2, tooth 35. (A) Preoperative periapical radiograph. (B) Clinical view of the tooth crown with the fiber post exposed to the oral cavity. (C) Clinical view of tooth crown after fiber post removal. (D) Periapical radiograph after removal of fiber post and filling material. (E) Periapical radiograph showing the coronal tooth fracture and the application of mineral trioxide aggregate (MTA) into perforation site. (F) Clinical view of the application of MTA into perforation site. (G) Postoperative periapical radiograph, after placement of a fiber post (H) 6-month follow-up. (I) 2-year follow-up, after the placement of a metal post and crown for prosthetic reasons. (J) 6-year follow-up. 


\section{DISCUSSION}

In this report of two cases, the management of unfavorable root perforations using MTA was presented.

Root perforations are complications that have an incidence of approximately $2.3 \%$ (14). A study reported that $47 \%$ of perforations occur during endodontic treatment, while $53 \%$ occur in the prosthetic phase (15). Another study reported that the presence of perforations, either pre-operative or during treatment, significantly affect the outcome of orthograde treatment (16). Additionally, large perforations are associated with higher pathological changes of periodontal tissues (14), as presented in both cases. The failure rate has been reported to be $16 \%$ when it is greater than $3 \mathrm{~mm}$, and $6 \%$ when it is $2-3 \mathrm{~mm}$ (17). The present case report showed healing and favorable evolution at 3 and 2-year follow-up in case 1 and 2, respectively.

It has been described that three clinical factors are relevant in the prognosis and healing of perforations: location, size and time (2). In both cases, the location factor was favorable since they were in the middle third of the roots. It has been described that the prognosis is worse in the so-called "critical zone", which corresponds to the gingival sulcus and the crestal attachments since greater bacterial contamination can be promoted, generating a periodontal pocket (2). On the other hand, regarding the size factor, in both cases, it was observed that the etiology was a previous post placement, which is considered unfavorable perforation due to the high amount of tissue that is excavated, and the difficulty of obtaining an adequate sealing (1). In case 2, the time factor aggravated the condition because the temporary restoration was adequately sealed for 3 months, which favored bacterial contamination and subsequent painful symptoms in the patient. Regarding this, it has been described that the faster the sealing, the better the prognosis (2).

The perforations sealing was performed using two different approaches, a single session and two sessions. In case 1, considering that the patient had undergone recent root canal treatment and had an adequate coronal sealing, the perforation was sealed performing a single session approach, which is characterized by the use of a calcium sulfate matrix, which is a resorbable material that sets quickly and serves as a suitable matrix for MTA (18). In addition, the perforation was irrigated with $2 \%$ chlorhexidine to avoid that a possible extrusion would have complicated the case. In case 2, considering that the tooth had been contaminated for a long time (3 months), it was decided to place calcium hydroxide in both the canal and the perforation to allow bacterial decontamination. Although calcium hydroxide generates areas of necrosis when it is in direct contact with tissue, it promotes tissue repair and mineralization due to the calcium ions that are released (19). Additionally, calcium hydroxide served as a matrix before the placement of the MTA (3). The use of matrices of calcium hydroxide or calcium sulfate prior to perforation sealing with MTA is based on the fact that MTA Angelus exhibits less sealing when not used with a matrix (11).

Various materials have been used for the repair of perforations, among them MTA (20). The MTA has been used for the repair of perforations due to its adequate physicochemical $(9,11)$ and biological $(4,10)$ properties. Clinical studies have shown that the use of this repair material promotes long-term success of perforation sites regardless of the location factor (20).

\section{CONCLUSION}

The application of MTA in iatrogenic perforations shows good results, allowing the maintenance of tooth function in the oral cavity.

Conflict of interests: The authors declare that they have no conflict of interests related to this related to this paper.

Ethical approval: Informed consent was signed by patients.

Funding: Fundação de Amparo à Pesquisa do Estado de São Paulo - FAPESP [Grant 2018/24662-6].

Author's contribution: All authors contributed substantially for the elaboration of this work.

Corresponding author:

Hernán Coaguila-Llerena 
Rua Humaitá 1680, Araraquara, 14801-903 SP, Brazil.

Phone number: + 55 (16) 3301-6398

E-mail: eric.coaguila.1@upch.pe

\section{BIBLIOGRAPHIC REFERENCES}

1. Tsesis I, Fuss Z. Diagnosis and treatment of accidental root perforations. Endod Top. 2006; 13(1):95-107.

2. Mohammed Saed S, Ashley MP. Root perforations: Aetiology, management strategies and outcomes. The hole truth. Br Dent J. 2016; 220(4):171-80.

3. Estrela C, Decurcio D de A, Rossi-Fedele G, Silva JA, Guedes OA, Borges ÁH. Root perforations: a review of diagnosis, prognosis and materials. Braz Oral Res. 2018; 32:133-46.

4. da Fonseca TS, Silva GF, Guerreiro-Tanomaru JM, et al. Biodentine and MTA modulate immunoinflammatory response favoring bone formation in sealing of furcation perforations in rat molars. Clin Oral Investig. 2019; 23(3):1237-52.

5. Baek SH, Plenk H, Kim S. Periapical tissue responses and cementum regeneration with amalgam, superEBA, and MTA as root-end filling materials. J Endod. 2005; 31(6):444-9.

6. Lee SJ, Monsef M, Torabinejad M. Sealing ability of a mineral trioxide aggregate for repair of lateral root perforations. J Endod. 1993; 19(11):541-4.

7. Parirokh M, Torabinejad M, Dummer PMH. Mineral trioxide aggregate and other bioactive endodontic cements: an updated overview - part I: vital pulp therapy. Int Endod J. 2018; 51(2):177-205.

8. Parirokh M, Torabinejad M. Mineral Trioxide Aggregate: a comprehensive literature review-Part I: chemical, physical, and antibacterial properties. J Endod. 2010; 36(1):16-27.

9. Coaguila-Llerena H, Ochoa-Rodriguez VM, CastroNúñez GM, Faria G, Guerreiro-Tanomaru JM, Tanomaru-Filho M. Physicochemical properties of a bioceramic repair material - BioMTA. Braz Dent J. 2020; 31(5):511-5.

10. Coaguila-Llerena H, Vaisberg A, Velásquez-Huamán Z. In vitro cytotoxicity evaluation of three root-end filling materials in human periodontal ligament fibroblasts. Braz Dent J. 2016; 27(2):187-91.
11. Hashem AAR, Hassanien EE. ProRoot MTA, MTAAngelus and IRM used to repair large furcation perforations: sealability study. J Endod. 2008; 34(1):59-61.

12. Marciano MA, Costa RM, Camilleri J, Mondelli RFL, Guimarães BM, Duarte MAH. Assessment of color stability of white mineral trioxide aggregate Angelus and bismuth oxide in contact with tooth structure. J Endod. 2014; 40(8):1235-40.

13. Parirokh M, Torabinejad M. Mineral trioxide aggregate: a comprehensive literature review-Part III: clinical applications, drawbacks, and mechanism of action. J Endod. 2010; 36(3):400-13.

14. Tsesis I, Rosenberg E, Faivishevsky V, Kfir A, Katz M, Rosen E. Prevalence and associated periodontal status of teeth with root perforation: a retrospective study of 2,002 patients' medical records. J Endod. 2010; 36(5):797-800.

15. Kvinnsland I, Oswald RJ, Halse A, Grønningsæter AG. A clinical and roentgenological study of 55 cases of root perforation. Int Endod J. 1989; 22(2):75-84.

16. Ng YL, Mann V, Gulabivala K. A prospective study of the factors affecting outcomes of non-surgical root canal treatment: Part 2: tooth survival. Int Endod J. 2011; 44(7):610-25.

17. Gorni FG, Andreano A, Ambrogi F, Brambilla E, Gagliani M. Patient and clinical characteristics associated with primary healing of iatrogenic perforations after root canal treatment: results of a long-term italian study. J Endod. 2016; 42(2):211-5.

18. Kratchman SI. Perforation repair and one-step apexification procedures. Dent Clin North Am. 2004; 48(1):291-307.

19. Dammaschke T, Stratmann U, Wolff P, Sagheri D, Schäfer E. Direct pulp capping with mineral trioxide aggregate: an immunohistologic comparison with calcium hydroxide in rodents. J Endod. 2010; 36(5):814-9.

20. Mente J, Leo M, Panagidis D, Saure D, Pfefferle T. Treatment outcome of mineral trioxide aggregate: repair of root perforations - long-term results. J Endod. 2014; 40(6):790-6.

Recibido : 07-04-2021

Aceptado : 20-08-2021 